TECHNICAL MATERIAL

\title{
What Factors Facilitate Regulatory Competence in Supervising The Safety of Nuclear Technology?
}

\author{
Marina MISHAR \\ Atomic Energy Licensing Board, Ministry of Science Technology and Innovation \\ 43800 Dengkil, Selangor D.E., Malaysia
}

\begin{abstract}
The proposed utilization of nuclear energy for electricity generation as the alternative energy source requires Atomic Energy Licensing Board (AELB), the Malaysian nuclear regulatory body taking key role in supervising the safety of the program. This study looked into factors influencing the competency of current AELB human resource as technical competency has been identified as one of the main contributors to the success of a civil nuclear power program. The four quadrant competency model developed by International Atomic Energy Agency was utilized as the required competency. A comprehensive study on 81 personnel from five states in different geographic regions of the country were carried out to investigate the impact of six factors related to competency (educational level, years of working experience, trainings attended, participation in technical committees, numbers of technical papers written and number of technical presentation presented) on four dependent measures in the areas of regulatory competency (legal basis, technical disciplines, regulatory practices and personal and interpersonal effectiveness). Multiple regression (method enter) identified factors that had significant contribution to level of competency while stepwise regression resulted in identifying predictors to enhance competencies. Results were mixed but each of the independent factors is a predictor to different competencies. This study had identified the best predictors that could significantly contribute to the enhancement of regulatory
\end{abstract}

\section{KEYWORDS: :nuclear power program, nuclear regulatory body, competency, competencies predictors}

\section{Introduction}

The establishment of the Malaysian Nuclear Power Corporation on 11 January 2011 has shown that the government of Malaysia is indeed, seriously looking into the option to use nuclear to generate electricity by 2021 as the long term solution to Malaysia's energy requirement. The Malaysian Nuclear Power Corporation is entrusted to spearhead planning the eventual deployment of nuclear power plants in Malaysia.

Nuclear power program requires long term oversight and therefore it is vital to develop sufficient national capabilities and expertise to take on the responsibilities in all aspects of running a nuclear plant including regulatory functions ${ }^{1)}$. An independent nuclearregulator is one of the essential institutions that could ensure the success of a nuclear power program. Atomic Energy Licensing Board (AELB) is the nuclear regulatory body in Malaysia, mandated through Atomic Energy Licensing Act 1984. In the preparation to embark into a nuclear power program, AELB needs to enhance the level of competency of its human capital efficiently and effectively to ensure it can fulfill its roles and responsibilities.

This empirical study hopes toidentify factors that contributed to the enhancement of competency level. By indentifying the factors that influenced competency or

\footnotetext{
*Corresponding Author, Email: marina@aelb.gov.my

(C) 2012 Atomic Energy Society of Japan, All Rights Reserved
}

competency predictors, the existinglevel of competencies in AELB to carry out future regulatory functions on nuclear power program activities can be enhanced effectively. The findings may also be used to assist AELB in determining the main pedagogy for its human resource development program to effectively enhanced its technical staffs' competency level.

\section{Nuclear Regulator Competency}

The International Atomic Energy Agency (IAEA) had developed a Four Quadrant Competency Model ${ }^{2}$ ) (shown in Figure 1) based on job/task analysis of four major functions of a nuclear regulatory body in overseeing the safety of nuclear power plant activities. The four quadrants comprised of four discrete sets of competencies but are coherent and consistent within the context of each quadrant.

The four major functions of a nuclear regulatory body are authorization; review and assessment; inspection and enforcement; and development of regulations and guides. Besides these four major functions, a nuclear regulatory body like AELB also has three supplementary regulation functions (i.e. research and development; emergency preparedness; and international cooperation) depending on their organizational structure.

A competent nuclear regulator enables it to make its own decision without depending on other technical agencies which at times are also owner of a license issued by the 


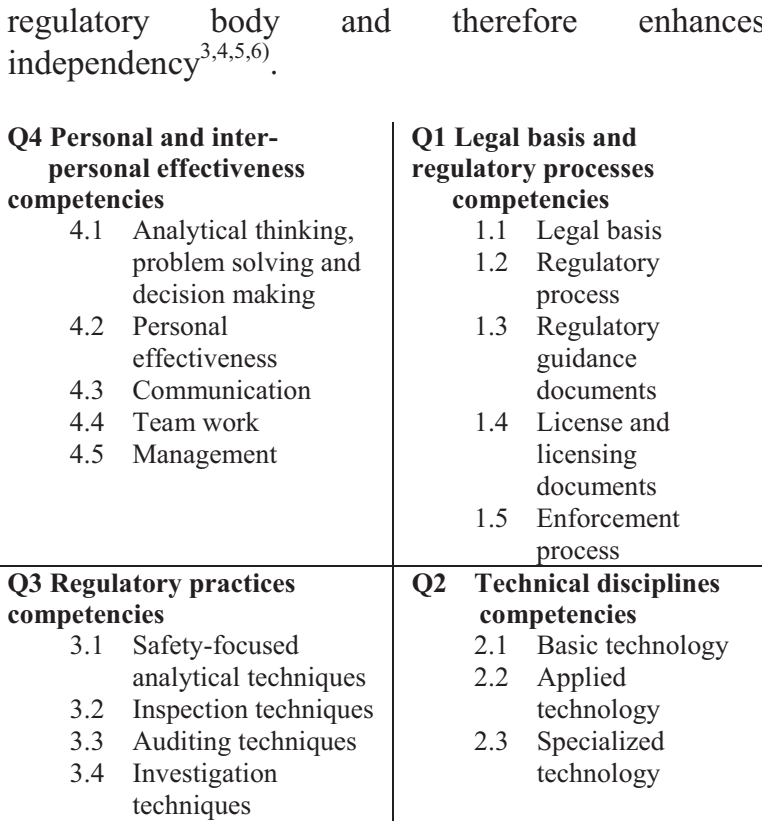

Fig.1 Nuclear Regulatory Body Competency Model.

\section{Factors Contributing to Competency}

Past literatures had identified that competency is enhanced through knowledge acquisition i.e. by learning and by doing ${ }^{7}$. Learning occurs through education and trainingwhere training is defined as a planned learning experience designed to create permanent changes in a person's knowledge, attitude and skill ${ }^{8}$. Some reseachers stressed that competency will not be achieve without experience ${ }^{9}$.

However, there are researchers that highlighted that a person's role in the organization and how the knowledge is used is more important10. Taking past studies into account, six independent parameters is identified and used in this study to determine the predictors to AELB's regulatory competency i.e. education level, training (number of days), working experience (years), number of committees joined, number of technical presentations given and number of technical paper written.

\section{Methodology}

A survey is carried out on all AELB's technical staff comprised of 81 staffs, working in 5 different locations throughout Malaysia. A questionaire utilizing the competency model in Figure 1 was given to the respondents and they were requested to select a response by choosing a point that represented their level of knowledge or skill or attitude based on a Likert scale format adapted from Dreyfus Model of Skill Acquisiton as shown in Table 2. At scale 3 , the respondent is identified as competent or had acquired the expected competencies to enable him/her toutilize his/her knowledge and skill and having the right attitude to perfom his/her task to the acceptable standard effectively.

The result of the competency level based on the self-assessed questionaire was used as the dependent parameters. The internal consistency as assessed by the Cronbach alpha was .934 (Q1), .857 (Q2), 953 (Q3) and $.952(\mathrm{Q} 4)$.

At the same time, all respondents were also requested to complete their curriculum vitae based on a given format that includes demographic data such as age, sex, years of service and educational background. Respondent's training records and records of technical activities such as technical presentations given, technical paper written and technical committee joined for the year 1999 to 2009 was reviewed to identify which competency quadrant each activity belongs to and were used as the independent parameter.

\section{Results}

The number of male and female respondents is almost equal at $56.8 \%$ male and $43.2 \%$ female with the majority of the respondents' age is in the range of 25 to 34 years $(61.7 \%)$. On the educational background, only $39.5 \%$ of the respondent had a minimum of bachelor degree. Equally, majority of the respondents $(60.5 \%)$ had only 5 years and less working experience in AELB.

In determining how strong academic level which denotes "learning" and number of years working which denotes "doing", influenced competency, correlation analysis was carried out. As expected, both education level and years of experience do statistically significantly influenced all 17 competencies. Education level had a very weak negative correlation $(-.235<\mathrm{r}<-.384 ; \mathrm{p}<0.05)$ with all competencies; the higher the education level, the higher the competency level. Number of years of experience had a slightly stronger positive correlation with all competencies in the competency model $(.296<\mathrm{r}<.545 ; \mathrm{p}<0.05)$; the higher the number of years working, the higher the level of competency.

Multiple regression (step wise) was then used to

Table 2 Competency Levels Adapted from Dreyfus Model of Skill Acquisition.

\begin{tabular}{|c|c|c|c|c|c|}
\hline $\begin{array}{c}\text { Competency } \\
\text { Level }\end{array}$ & $\begin{array}{c}1 \\
\text { Novice }\end{array}$ & $\begin{array}{c}2 \\
\text { Advance } \\
\text { Beginner }\end{array}$ & Competent & Proficient & $\begin{array}{c}5 \\
\text { Expert }\end{array}$ \\
\hline Details & $\begin{array}{c}\text { Have some } \\
\text { awareness or } \\
\text { knowledge and } \\
\text { able to explain } \\
\text { what it means } \\
\text { only }\end{array}$ & $\begin{array}{l}\text { Have a good } \\
\text { understanding of } \\
\text { the basic concept, } \\
\text { principles, theory } \\
\text { but not yet able to } \\
\text { explain about the } \\
\text { applications. }\end{array}$ & $\begin{array}{l}\text { Able to } \\
\text { demonstrate, } \\
\text { apply, practice, } \\
\text { perform with } \\
\text { skills to work } \\
\text { satisfactorily with } \\
\text { minimum }\end{array}$ & $\begin{array}{l}\text { Able to coach, } \\
\text { teach or evaluate } \\
\text { others on how to } \\
\text { apply or perform } \\
\text { the competency } \\
\text { effectively }\end{array}$ & $\begin{array}{l}\text { Able to create, } \\
\text { develop, } \\
\text { integrate, } \\
\text { re-engineer, } \\
\text { formulate new } \\
\text { models, process, } \\
\text { ideas pertaining }\end{array}$ \\
\hline
\end{tabular}


determine the predictors to each competency in the competency model. Result of the regression analyses is shown in Table 1 where the the strength of prediction from a multiple regression equation is measured by the square of the multiple correlation coefficient, $\mathrm{R}^{2}$. Based on Table 3, number of technical presentations given contributed to $42.2 \%$ of the level of competence for legal basis competency (quadrant 1, 1.1). However, number of technical presentations supported by number of technical papers written, contributes to $46.5 \%$ to competency level. Different independent parameters are predictors to different competency and each competency has a minimum of one model of predictors that contributed to its level.

Table 1 Multiple Regression Analysis Result: Predictors to Nuclear Regulatory Competence.

\begin{tabular}{|c|c|c|}
\hline $\begin{array}{c}\text { Com- } \\
\text { petency }\end{array}$ & Model/Predictors & $\mathbf{R}^{2}$ \\
\hline \multirow[t]{2}{*}{ Q1: 1.1} & a) No. of Presentations & .422 \\
\hline & b) No. of Presentations \& Papers & .465 \\
\hline \multirow[t]{3}{*}{1.2} & a) No. of Presentations & .305 \\
\hline & b) No. of Presentations \& Edu. Level & .377 \\
\hline & c) No. of Presentations, Edu. Level \& Years of Exp. & .415 \\
\hline \multirow[t]{2}{*}{1.3} & a) No. of Presentations & .319 \\
\hline & b) No. of Presentations \& Papers & .354 \\
\hline \multirow[t]{3}{*}{1.4} & a) No. of Presentations & .263 \\
\hline & b) No. of Presentations \& Edu. Level & .318 \\
\hline & c) No. of Presentations, Edu. Level \& Years of Exp. & .374 \\
\hline \multirow[t]{2}{*}{1.5} & a) Years of Experience & .174 \\
\hline & b) Years of Experience \& No. of Papers & .240 \\
\hline $\mathrm{Q} 2: 2.1$ & a) No. of Committes & .190 \\
\hline \multirow{2}{*}{ Q3 : 3.1} & a) Years of Experience & .145 \\
\hline & b) Years of Experience \& No. of Papers & .211 \\
\hline \multirow[t]{2}{*}{3.2} & a) Years of Experience & .158 \\
\hline & b) Years of Experience \& No. of Papers & .232 \\
\hline \multirow[t]{2}{*}{3.3} & a) No of Papers & .137 \\
\hline & b) No. of Papers \& Years of Experience & .185 \\
\hline \multirow[t]{3}{*}{3.4} & a) No. of Committes & .156 \\
\hline & b) No. of Committes \& Years of Experience & .215 \\
\hline & c) No. of Committes, Years of Exp.\& Edu. Level & .255 \\
\hline \multirow[t]{3}{*}{ Q4 : 4.1} & a) No of Papers & .160 \\
\hline & b) No. of Papers \& Years of Experience & .208 \\
\hline & c) No. of Papers, Years of Experience \&Edu. Level & .251 \\
\hline \multirow[t]{5}{*}{4.2} & a) No of Papers & .198 \\
\hline & b) No. of Papers \& Years of Experience & .265 \\
\hline & c) No. of Papers, Years of Experience \& Edu Level & .281 \\
\hline & d) No. of Papers, Years of Experience, Educational & \\
\hline & Level \& Training & .353 \\
\hline \multirow[t]{3}{*}{4.3} & a) No of Papers & .184 \\
\hline & b) No. of Papers \& Years of Experience & .274 \\
\hline & c) No. of Papers, Years of Experience\& Training & .363 \\
\hline \multirow[t]{3}{*}{4.4} & a) Educational Level & .184 \\
\hline & b) Educational Level \& Years of Experience & .294 \\
\hline & c) Educational Level, Years of Experience\& Training & .340 \\
\hline \multirow[t]{2}{*}{4.5} & a) Educational Level & .197 \\
\hline & b) Educational Level \& Years of Experience & .379 \\
\hline
\end{tabular}

\section{Conclusion}

Based on the demographic data, AELB is a young organization with a majority of its technical staff has 5 years or less experience and aged less than 35 years. Taking into consideration the time required to establish a nuclear power plant, AELB current staffing composition is at an ideal time for Malaysia to embark on a nuclear power program as majority $(60 \%)$ of its existing workforce will still be in AELB during the nuclear plant's operation phase.

This study had shown that education level(learning) and experience (doing) have a significant relation with competency level. By examining and comparing the relations among learning and doing components i.e. educational level, training, years of experience, number of techical presentation and technical papers done and number of committees joined, this study managed to determine specific predictors that contributed or had influenced AELB technical competency. This study had also provided the empirical data to support the development of an effective human resource program.

\section{References}

1) El-Baradei, M. (2009). Speech at Beijing International Ministerial Conference on Nuclear Energy in the $21^{\text {st }}$ Century. 20 April 2009, Beijing.

2) IAEA (2000). Legal and Governmental Infrastructure for Nuclear, Radiation, Radioactive Waste and Transport Safety, Safety Series No. GS-R-1. Vienna, Austria.

3) Borchardt, W. (2009), Safety and Regulatory Issues to Address When Considering Nuclear Energy. Beijing Ministerial Conference - Technical Session 3. 22 April 2009. Beijing.

4) IAEA, (2006), Risk Management of Knowledge Loss in Nuclear Industry Organizations, Vienna, Austria.

5) OECD, (2004). Committee on Nuclear Regulatory Activities: A Historical Perspective (1989 - 2004, NEA/CNRA/R(2004), 16 November 2004, Paris, France.

6) IAEA, (2001), Training the Staff of the Regulatory Body for Nuclear Facilities: A competency framework, TECDOC-1254. Vienna, Austria.

7) Krogh, G. \& Roos, J. (1996). Arguments on Knowledge and Competence. In Krogh, G. \& Roos, J. (ed). Managing Knowledge: Perspectives in Cooperation and competition, 100-108. Cambridge: United Kingdom University Press.

8) Kirkpatrik, D.L. (1998). Evaluating Training Programs: The Four Level. Second Edition. San Francisco: Berrett-Koehler Publishers, 19-24.

9) Abd. Hair Awang, Rahmah Ismail, Azimi Hamzah, Asma Ahmad \& Jejak Uli (2008). Kompetensi tenagakerja: keseimbangan antara tuntutan majikan dan penguasaan pelatih. Jurnal Pembangunan Belia Malaysia 1(12):135-164.l

10) Garavan, T. \& McGuire, D. (2001). Competencies \&Workplace Learning: Some Reflections on the Rhetoric \& the Reality. Journal of Workplace Learning. 13(4): 144 - 164. 